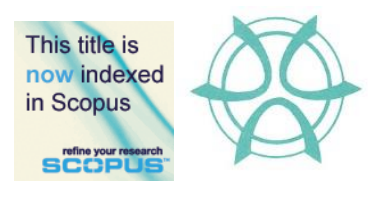

PLANNING MALAYSIA:

Journal of the Malaysian Institute of Planners

VOLUME 17 ISSUE 1 (2019), Page 128 - 137

\title{
RURAL AGRO-TOURISM AND LOCAL COMMUNITY INCOME: THE CASE STUDY OF CLUSTERED HOMESTAYS IN KELANTAN AND TERENGGANU
}

\author{
Syahriah Bachok ${ }^{1}$, Hafizah Hasbullah ${ }^{2} \&$ Tuan Anisdina Tuan Mohd Amin ${ }^{3}$ \\ ${ }^{1,2,3}$ Kulliyyah of Architecture and Environmental Design \\ INTERNATIONAL ISLAMIC UNIVERSITY MALAYSIA
}

\begin{abstract}
This research outlines the analysis of income generation basing on agro-cultural tourism of homestays under the purview of Ministry of Tourism and Culture of Malaysia. Using a case study of Kelantan and Terengganu, the research elaborates on the levels of income generated from agro-tourism, distributions, administrations, factors leading to the success of homestays in generating additional income and strategies of infrastructural improvements of homestay. Tourism is one of the largest contributing sectors (13\%) to the National Gross Product (RM153 billion) in 2015. Agro-tourism provide opportunities for the visitors to stay and experience the life of an agriculture community in rural areas. Kelantan and Terengganu are rich with agricultural produce, thus have the advantage of showcasing the unique attractions to various tourists' types. Homestays in Kelantan and Terengganu are limited in research. Hence, this research aims to assess the rural agro-tourism and local community income generated from homestays in Kelantan and Terengganu.
\end{abstract}

Keyword: homestay, agro-tourism, tourism, Kelantan, Terengganu 
PLANNING MALAYSIA

Journal of the Malaysia Institute of Planners (2019)

\section{INTRODUCTION}

This study centres around the analysis of income generation basing on agrocultural-tourism among rural communities. The focus is on homestay operations and economic opportunities generated, specifically concentrating on case studies of Kelantan and Terengganu. In particular, the ambit of the research is those homestays operating upon registration with the Malaysian Ministry of Tourism and Culture (MOTAC), regulated and monitored by relevant agencies. The clusters of 8 homestays in Kelantan and 10 homestays in Terengganu can be associated with 152 and 185 operators respectively, according to MOTAC.

Table 1 highlights the tourist arrivals and their stay in homestay accommodation in Kelantan and Terengganu. It shows the figures for Kelantan have slightly decreased from year 2012 to 2013 and decreased dramatically from year 2014 to 2015. Meanwhile, those of Terengganu show good performance as they were increasing year by year, except in 2014 and 2015. It can be clearly seen that there has been a large increase in the tourist arrivals from homestay accommodation in Kelantan for the years 2013 to 2014 as due to the reduction in the cost of the homestay package. In addition, the public and private sectors also vigorously promoted the homestay programme.

Table 1: Tourist arrivals and their stay in homestay accommodation

\begin{tabular}{cccccccc}
\hline State & 2010 & 2011 & 2012 & 2013 & 2014 & 2015 & 2016 \\
\hline Kelantan & 1,048 & 2,021 & 3,935 & 3,201 & 11,152 & 5,991 & 3,972 \\
Terengganu & 2,999 & 3,628 & 4,754 & 4,978 & 3,066 & 2,724 & 4,058 \\
\hline Source: MOTAC, 2017
\end{tabular}

This is one of the critical success factors considered when analysing the data in this research. However, these figures are still comparatively lower than those of national average, especially when contrasted against Melaka, Penang and Klang Valley tourists' arrival. Many unsuccessful stories of homestays have been attributable to unattractive destination such as the homestays location and the support facilities including the infrastructure installation (Palmer, Wolff, \& Cassidy, 2008; Chew 2009; Lussetyowati, 2014; Ismail, Masron, \& Ahmad, 2014; Huibin, Marzuki, \& Abdul Razak, 2013).

Hence, it is this gap in the literature that this proposed research is focusing to bridge, to come out with relevant improvements to the existing homestays. By increasing homestays' attractiveness for both the domestic and international tourists, more arrivals and more income generated from these activities can be realised. 
Syahriah Bachok, Hafizah Hasbullah \& Tuan Anisdina Tuan Mohd Amin

Rural Agro-Tourism and Local Community Income: The Case Study of Clustered Homestays in Kelantan and Terengganu

\section{LITERATURE REVIEW}

\section{Homestay}

Homestay programme is a community-based programme where tourists can have interaction and direct experience of the day-to-day life of the community (Thapaliya, Rai, Shrestha, Parajuli, \& Pandey, 2012). Wipada (2007) further elaborated that homestay is one of the type of lodging where tourist stay with the homeowners with the intention to learn culture and lifestyle from the homeowner who is willing to share their culture. Moreover, homestays gain their popularity as they enable visitors to experience life as it is lived day to day in the host country. These types of accommodations have the good potential to promote cultural exchange by sharing life and family experiences (Richardson, 2004).

In Malaysia, homestay accommodation is mainly operated and organized by rural communities or village residents. According to MOTAC (2017), a homestay programme gives tourists the opportunity to stay with a chosen family, interact and experience the daily life of their homestay family and learn the culture and lifestyle of the rural community in Malaysia. It focuses more on lifestyle and experience, including cultural and economic activities.

\section{Rural Agro-Tourism}

The concept of agro-tourism is a direct expansion of eco-tourism and one of the important segments of the rural tourism, which encourages visitors to experience the limelight of agricultural life at first hand. Agro-tourism is a segment and part of rural tourism, and relates to tourism on farms. To see unique culture and life style in rural areas, tourists have to visit rural places where traditional lifestyle and culture are preserved in its traditional form (Gurung, Simmons, \& Devlin, 1996).

\section{Infrastructure}

The essence of every tourism destination is its tourism infrastructure facilities. The quality of a destination's infrastructure is a key part of its tourism offering, particularly in relation to the visitor's experience being at the destination. Tourism infrastructure can be considered as the physical elements that are designed, planned and developed to cater visitors' needs. Tourism infrastructure comprises both 'soft' and 'hard' infrastructure. Hard infrastructures are tangible, physical and durable installation utilities, facilities and amenities to support tourism destination accessibility and make attraction more competitive for the enjoyment and experiencing of tourists. Soft infrastructures are those intangible, intellectual, human capitals, skills and installation of facilities and amenities. 
PLANNING MALAYSIA

Journal of the Malaysia Institute of Planners (2019)

\section{Study Site: Kelantan and Terengganu, Malaysia}

By 2016, there were ten (10) and eight (8) homestays operating in Terengganu and Kelantan respectively (Table 2). Besides the accommodation, the visitors will experience a variety of activities in the homestay programme. The activities offered to the tourist include agro-based activities such as rubber tapping, palm oil processing, aquaculture, fishing, turtle hatching, agriculture product and handicraft making, and "Trigona/ Kelulut" Honey farm visit. On the other hand, the non-agro-based activities in this homestay programme include visiting to famous places, river cruising, village touring, fireflies watching, traditional culture night, visiting historical sites, cooking traditional food activity and visiting cultural and norms places (MOTAC, 2017).

Table 2: List of homestay in Terengganu and Kelantan

\begin{tabular}{|c|c|}
\hline Homestay in Terengganu & Homestay in Kelantan \\
\hline $\begin{array}{l}\text { 1. Homestay Kg. Teluk Ketapang, Kuala } \\
\text { Terengganu. }\end{array}$ & $\begin{array}{l}\text { 1. Homestay Kg. Pantai Suri, } \\
\text { Tumpat }\end{array}$ \\
\hline Homestay Felda Selasih, Besut & 2. Homestay Renok Baru, Gua \\
\hline Homestay Felcra Keruak, Jerteh & Musang \\
\hline Homestay Kubang Depu, Setiu & 3. Homestay Bukit Jering, Jeli \\
\hline Homestay Kg. Rhu 10, Kuala Nerus & 4. Homestay Kg. Batu Papan, Gua \\
\hline 6. Homestay Kg. Pulau Duyong, Kuala & Musang \\
\hline $\begin{array}{l}\text { Terengganu } \\
\text { Homestay Kg. Buloh, Hulu Terengganu }\end{array}$ & $\begin{array}{l}\text { 5. Homestay Kg. Kubang Telaga, } \\
\text { Bachok }\end{array}$ \\
\hline Homestay Jerangau, Dungun & 6. Homestay Seterpa, Kota Bharu \\
\hline 9. Homestay Kg. Pasir Raja, Dungun & 7. Homestay Kg. Jelawang, Dabong \\
\hline 10. Homestay Seri Bandi, Kemaman & 8. Homestay Kemunchup, Machang \\
\hline
\end{tabular}

\section{RESEARCH METHODOLOGY}

This paper deployed two data gathering methods for primary and secondary data. For the primary data, unstructured interview session was carried out on homestay operators identifying factors relating to homestay quality and success, infrastructure support, experiences with agro-tourism as well as issues and problems relating to tourism in general in Kelantan and Terengganu. As such, focus group discussion were held over a few sessions, both in Kelantan and Terengganu during data collection period. Tourism authority officers were interviewed to confirm and validate the findings of both content analysis and the transcribed or narration of focus group discussion. Focus group discussion were undertaken from August, 2016 until February 2017 at homestay locations as well as at the offices of the relevant agencies. In total, this research conducted 139 interviews with homestay owners. 
Syahriah Bachok, Hafizah Hasbullah \& Tuan Anisdina Tuan Mohd Amin

Rural Agro-Tourism and Local Community Income: The Case Study of Clustered Homestays in Kelantan and Terengganu

\section{ANALYSIS AND DISCUSSION}

\section{Homestays in Kelantan and Terengganu}

There are 152 homeowners from 8 villages that offered 182 rooms for tourist to stay under the homestay programme in Kelantan. Meanwhile, in Terengganu the homestay programme involves 10 villages with 185 homeowners that provide 187 rooms for tourist to stay (MOTAC, 2017).

\section{Infrastructure}

Physical infrastructure was available and provided with easy access of homestays such as airport, seaport/jetties, road network, and communication facilities as well as electricity, water and other utilities.

\section{Socio Demographic}

Gender distribution of the respondents was unequally distributed. The majority of those participating in the focus group discussion was female, contributing to more than 71 percent (three quarter) of the 139 respondents. This, however would provide a balanced homestay environment and activities for both males and females renters. Age pattern was unequal with more than $35 \%$ of respondents being in their 50s, followed by 60 to 69 years old (32\%), 40 to 49 years old (20\%), 70 and above years old (19\%), 30 to 39 years old (3\%) and 20 to 29 years old (1\%) (Table 3).

Table 3: Age range of homestay owners (respondents) $(n=139)$

\begin{tabular}{c|c|c}
\hline \multicolumn{2}{c|}{ Age range (years old) } & Percent \\
\hline \multirow{4}{*}{ Per Homestay unit } & $20-29$ & 1.4 \\
& $30-39$ & 2.9 \\
& $40-49$ & 20.1 \\
& $50-59$ & 34.5 \\
& $60-69$ & 32.4 \\
& 70 and above & 8.6 \\
\cline { 2 - 3 } & Total & 100.0 \\
\hline
\end{tabular}

Source: Study Visit, 2017

Education level was also unfairly distributed with the highest proportion (55\%) having completed secondary school level of education. This would reflect the types of training and skills possessed by the owners and operators of these clustered homestays. The type of employment also varied, with small proportion being part-time workers $(4 \%)$. The majority $(63 \%)$ were in others group of workers. As a result, the household monthly income captured was also not equally distributed. Some $36 \%$ of the households from which the respondents come from were earning between RM1,000 and RM1,999, an income range considered lower 
than the national average. 25\% of the homestay owners earned less than RM1,000 monthly. It can be preliminarily concluded that homestays in Kelantan and Terengganu were operated by low income households.

\section{Initial Preparation of Operation}

Some $45 \%$ had training on product presentation while only $24 \%$ had experiences preparing a simple book keeping. Due to various reasons including demographics, only $27 \%$ had computing skills training. Training agencies were limited to only several including MOTAC, KETENGAH, Co-Operative College of Malaysia, Ministry of Health, KESEDAR, INFRA and a collaboration training session by KESEDAR and INFRA.

Fiscal and monetary initial investment began at the level of RM100 up to RM250,000. Most $(61 \%)$ of the participants started their initial investment below RM1,000. About 9\% invested between RM5,000 to RM6,999, and 6\% invested as much as RM1,000 to RM2,999 for their homestays, while only 3\% made investment of an amount ranging RM7,000 to RM8,999. Detailed distribution of the initial investment is presented in Table 4.

Table 4: Investment range by homestay owners $(n=139$

\begin{tabular}{l|c|c}
\hline \multicolumn{2}{|c|}{ Investment Range } & Percent \\
\hline \multirow{5}{*}{ Per homestay unit } & below RM999 & 61.2 \\
& RM1,000 - RM2,999 & 8.6 \\
& RM3,000 - RM4,999 & 5.0 \\
& RM5,000 - RM6,999 & 9.4 \\
& RM7,000 - RM8,999 & 2.9 \\
& RM9,000 - RM10,999 & 4.3 \\
& RM11,000 and above & 8.6 \\
\cline { 2 - 3 } & Total & 100.0 \\
\hline
\end{tabular}

\section{Operational Homestays}

Years of the beginning of the homestay operation ranged from 1996 (11\%) until $2016(8 \%)$. In other words, some homestays have been operating for more than two decades, while others were as young as one year. The variation explained the dispersion of levels of success and sustenance of the operation.

MOTAC's visit and recognition were important in sustaining and maintaining the quality of homestays in Kelantan and Terengganu. The visit runs every three years. A village selected to participate in the homestay programme must meet specific criteria and comply with guidelines issued by MOTAC in order for homestay programmes to be carried out effectively and efficiently. Recognition process started from the date when an application to join the homestay programme was made. 
Syahriah Bachok, Hafizah Hasbullah \& Tuan Anisdina Tuan Mohd Amin

Rural Agro-Tourism and Local Community Income: The Case Study of Clustered Homestays in Kelantan and Terengganu

\section{Visitors and Stayers of Homestays}

A range of one to 13 rooms were on offer at any one time by the participants attending the focus group discussion session. The majority (42\%) had one bedrooms for rent, followed by two rooms (36\%). Three rooms were offered by only a small number $(14 \%)$ of the respondents. The revenue received from rental per room/house ranged from RM30 to RM150 per night. Some $31 \%$ homestay owners charged RM80 per night, while about 20\% charged RM50. Some $19 \%$ charge RM60 per night, while $10 \%$ charged a nightly rate of RM40.

\section{Agro-based and Non Agro-based Activities}

The most popular agro-based activities were agriculture product and handicraft making (84\% of respondents), rubber tapping (64\%), fishing boat trips $(57 \%)$, palm oil processing (47\%), aquaculture (34\%), and turtle hatching (6\%). Some homestay owners also prepared activities such as extracting honey (4\%), production process of chilli sauce (4\%), visiting orchard (4\%) and visits to paddy field $(2 \%)$.

Meanwhile, non-agro-based activities were also conducted by the homestay owners as attractions in the homestay packages. Respondents were with provided traditional culture night experience (95\%), village tours $(94 \%)$, traditional food cooking (94\%), river cruise (69\%), historical site visits $(48 \%)$ and fireflies watching $(9 \%)$.

\section{Benchmark Case Study}

In Kelantan and Terengganu, the MOTAC auditing visits was only one or twice a year, in Banghuris and Dorani, such visits were more frequent, being three times in a year (Wagiman, personal communication, March 3, 2017). Through these visits, homestay standards and quality are ensured to be at the highest level, consistently. During the visits, audits and assessment of quality and quantity of services are made, remarks on improvement are provided for actions to be taken by the homestay management committees before next visits are initiated.

Individual promotions of own homestay communities are more rigorous and frequent in Banghuris and Dorani compared to those of Kelantan and Terengganu. Similarly, interpretation of local products, agricultural produce and eco-tourism activities by homestay owners to international inbound tourists were made more meticulously and extensively in Banghuris and Dorani compared to those of Kelantan and Terengganu homestays.

Table 5: Comparison between benchmark and case studies

\begin{tabular}{|c|c|c|}
\hline & $\begin{array}{c}\text { Banghuris and Dorani } \\
\text { Homestay, Selangor }\end{array}$ & $\begin{array}{c}\text { Kelantan and Terengganu } \\
\text { Homestay }\end{array}$ \\
\hline Operating Year & 1996 & 2006 (22\% of respondents) \\
\hline
\end{tabular}




\begin{tabular}{|c|c|c|}
\hline Training Area & $\begin{array}{ll}\text { i) } & \text { Customer service } \\
\text { ii) } & \text { Product presentation } \\
\text { iii) } & \text { Simple book keeping } \\
\text { iv) } & \text { Computer Skills } \\
\text { v) Tour Guide } \\
\text { vi) Language: English, Japan, } \\
\text { Korea }\end{array}$ & $\begin{array}{l}\text { i) Customer service } \\
\text { ii) Product presentation } \\
\text { iii) Simple book keeping } \\
\text { iv) Computer Skills } \\
\text { v) Language: English, Japan }\end{array}$ \\
\hline Rooms for rent & 1 and 2 & $\begin{array}{l}1 \text { ( } 42 \% \text { of respondents); } \\
2 \text { (36\% of respondents) }\end{array}$ \\
\hline $\begin{array}{l}\text { Cost for rental } \\
\text { rooms }\end{array}$ & $\begin{array}{l}\text { RM120 per head/night } \\
\text { (Banghuris) } \\
\text { RM100 per head/night (Dorani) }\end{array}$ & $\begin{array}{l}\text { RM } 80 \text { per head/night ( } 31 \% \text { of } \\
\text { respondents) } \\
\text { RM50 per head/night ( } 20 \% \text { of } \\
\text { respondents) }\end{array}$ \\
\hline $\begin{array}{l}\text { Tourist per } \\
\text { month }\end{array}$ & $\begin{array}{l}30 \text { (Banghuris), } 10,000-12,000 \\
\text { tourist annually } \\
10 \text { (Dorani), 5,000 tourist } \\
\text { annually }\end{array}$ & $\begin{array}{l}1(35 \% \text { of respondents }) \\
2(29 \% \text { of respondents })\end{array}$ \\
\hline $\begin{array}{l}\text { Annual Income } \\
\text { from Homestay }\end{array}$ & $\begin{array}{l}\text { RM2000 - RM3000 } \\
\text { (per month/Banghuris) }\end{array}$ & $\begin{array}{l}\text { RM200(26\% of respondents) } \\
\text { RM300(20\% of respondents) }\end{array}$ \\
\hline $\begin{array}{l}\text { Agro-based } \\
\text { activities }\end{array}$ & $\begin{array}{l}\text { i) Tours to Coffee, Rubber } \\
\text { and Orchard Plantation } \\
\text { (Banghuris) } \\
\text { ii) visit to paddy field, banana } \\
\text { and potato chips factory } \\
\text { (Dorani) } \\
\text { iii) Rubber tapping } \\
\text { iv) Fishing } \\
\text { v) Agriculture product \& } \\
\text { Handicraft }\end{array}$ & $\begin{array}{ll}\text { i) } & \begin{array}{l}\text { Agriculture product \& } \\
\text { Handicraft ( } 84 \% \text { of } \\
\text { respondents) }\end{array} \\
\text { ii) } & \begin{array}{l}\text { Rubber tapping ( } 64 \% \text { of } \\
\text { respondents) }\end{array} \\
\text { iii) } & \text { Fishing (57\% of } \\
\text { respondents) } \\
\text { iv) }\end{array}$ \\
\hline MOTAC visit & $\begin{array}{l}3 \text { times annually (Banghuris) } \\
\text { Once a year (Dorani) }\end{array}$ & $\begin{array}{l}\text { Once a year ( } 46 \% \text { of } \\
\text { respondents) } \\
\text { Twice a year ( } 30 \% \text { of } \\
\text { respondents) }\end{array}$ \\
\hline Infrastructure & $\begin{array}{ll}\text { i) } & \text { Multipurpose Hall } \\
\text { ii) } & \text { Canteen } \\
\text { iii) } & \text { Homestay office } \\
\text { iv) } & \text { Jetty (fishing) } \\
\text { v) } & \text { Recreational area }\end{array}$ & $\begin{array}{ll}\text { i) } & \text { Community Hall ( } 55 \% \text { of } \\
\text { respondents) } \\
\text { ii) } & \text { Free WiFi ( } 11 \% \text { of } \\
\text { respondents) }\end{array}$ \\
\hline
\end{tabular}

Source: Study Visit, 2017

\section{CONCLUSION AND RECOMMENDATIONS}

It can be concluded that incomes generated from agro-tourism related homestay activities in Kelantan and Terengganu are currently not sustainable. It is very difficult for the owners to maintain and manage their homestays and sustain the 
Syahriah Bachok, Hafizah Hasbullah \& Tuan Anisdina Tuan Mohd Amin

Rural Agro-Tourism and Local Community Income: The Case Study of Clustered Homestays in Kelantan and Terengganu

living standard solely based on the receipts from homestays rentals. If the income continues to be at such low levels, homestays may have to seize operation in the very near future.

Based on other success factors such as tourist annual, repeat visits, soft infrastructure, rental receipts and assets/wealth accumulation, Kelantan and Terengganu homestays could not be classified as successful. Hence, to improve and upgrade these circumstances, the following are recommended as way forward for these homestays.

\section{Making Homestay A Primary Activity of Agro-Based Tourism}

It is recommended that homestays to be a primary activity of agro-based tourism. First, homestay experiences must be upgraded to be at par with three-star hotels or motel quality where the accommodations provided deliver a broad range of amenities such as good quality service, design and physical attributes that match guest/renters expectations. Beddings, toilets, living rooms and kitchen must be clean, well-planned and laid out, and easily maintained.

\section{Increasing the Income of Agro-Based Tourism and Homestay Activities}

Income can be increased through value adding the local produce. If raw materials are marketed, the values are lower, hence income for homestay owners can be stagnant. However, if the raw materials are processed, packed packaged attractively, pickled or accentuated to have better longevity and durability, upgraded and researched into medicinal herbs and tablets as well as aqua-fishery herbal essences, marketed rigorously and exported in the highest quality; income can be increased by many folds.

\section{Motivating and Supporting the Success Factors of Homestay}

The success of Homestays in Banghuris and Dorani and other ASEAN examples (Ban Rai Kong Khing in Chiang Mai, Koh Yao Noi, Thailand and Homestay Adiluhung, Yogyakarta) are due to the initiatives, strong willed and knowledgeable communities running the homestay operations. Investing in human resources or human capital are the long term strategy suited for Kelantan and Terengganu homestay operations.

\section{Upgrading Added Value of Agro-Based Activities}

Upgrading of local produce would include strategies of diversification, intensification, interpretation and research and development. Products must be researched and developed to identify their further potential as medicinal herbs or essence or tablets. Products quantity can also be intensified through mass production in manufacturing plants. Durability and longevity of produce can be ensured by high quality packing and packaging. Modernizing the product 
processing sectors using the efficient equipment also is one of the way to value addition and processing of local agro-products.

\section{Developing Soft Infrastructure among Homestay Operators}

Soft infrastructure includes skills, training, motivation, experience and knowledge. Formal training and education can be initiated in areas of agro-based research and development. Regular workshops, training and homestay operators/ owners meetings help reinforce best practices and address new issues. While learning soft skills is not simply "book learning", there still must be as aspect of education on best practices.

\section{ACKNOWLEDGEMENT}

This research was supported by the National Property Research Coordinator (NAPREC) under the real estate valuation field.

\section{REFERENCES}

Chew, M. M. (2009). Cultural sustainability and heritage tourism: Problems in developing bun festival tourism in Hong Kong. Journal of Sustainable Development, 2(3), 34-42.

Gurung, G., Simmons, D., \& Devlin, P. (1996). The evolving role of tourist guides: The Nepali experience. In R. Butler and T. Hinch (Eds.), Tourism and indigenous peoples (pp.107-128). London: International Thomson Business Press.

Huibin, X., Marzuki, A., \& Abdul Razak, A. (2013). Conceptualizing a sustainable development model for cultural heritage tourism in Asia. Theoretical and Empirical Research in Urban Management, 8(1), 51-66.

Ismail, N., Masron, T., \& Ahmad, A. (2014). Cultural heritage tourism in Malaysia: Issues and challenges. SHS Web of Conference, 12, 10159.

Lussetyowati, T. (2015). Preservation and conservation through cultural heritage tourism case study: Musi Riverside Palembang. Procedia Social and Behavioral Science, 184, 401-406.

Ministry of Tourism and Culture Malaysia [MOTAC] (2017). Homestay. Retrieved March 2, 2017, from http://www.motac.gov.my/.

Palmer, C. T., Wolff, B., \& Cassidy, C. (2008). Cultural heritage tourism along the Viking Trail: An analysis of tourist brochures for attractions on the Northern Peninsula of Newfoundland. Newfoundland and Labrador Studies, 23(2).

Richardson, K. (2004, October). Homestay: Opening a world of opportunity. Australian International Education Conference. October 8, 2004, Sydney, Australia.

Thapaliya, M., Rai, G. S., Shrestha, A., Parajuli, B., \& Pandey, O. (2012). Home-Stay: Assessment in Lwang Ghalel. Nepal Tourism and Development Review, 2.

Wipada, U. (2007). Criteria creation for management evaluation of Thai homestay: A case study of Ubonratchathani Province, Thailand (Master's thesis). Mahidol University, Bangkok, Thailand 